\title{
Status of Logania falcata and L. sp. aff. albiflora (Loganiaceae)
}

\author{
Anthony J. Whalen ${ }^{1}$ and Barry J. Conn ${ }^{2}$
}

${ }^{1}$ Department of the Environment and Heritage, GPO Box 787, Canberra ACT 2601, Australia

${ }^{2}$ National Herbarium of New South Wales, Mrs Macquaries Road, Sydney NSW 2000, Australia

\begin{abstract}
Logania falcata Gand. is here lectotypified and reduced to the synonymy of L. albiflora R.Br. Logania sp. aff. albiflora (sensu Conn 1995a) is here regarded as a distinct species and formally named Logania granitica A.J.Whalen \& B.J.Conn.
\end{abstract}

\section{Introduction}

The taxonomic revision of Logania section Logania (Conn 1995a) recognised several variants within Logania albiflora. However, none of these were formally circumscribed. This paper re-evaluates the status of Logania sp. aff. albiflora sensu B.J.Conn (Conn 1995a) based on extensive field studies and examination of ex situ plants cultivated at the Australian National Botanic Gardens, Canberra (Australian Capital Territory). It was necessary to re-evaluate the typification of Logania falcata Gand.because it appears, at least in part, to be conspecific with L. sp. aff. albiflora sensu B.J.Conn (1995a).

The herbarium collections examined during this study are cited according to the natural regions of Victoria (Conn 1993) and subdivisions of New South Wales (as cited in Harden 1990). The inflorescence terminology used in the description of L. granitica is based on Conn (1995b).

\section{Taxonomy}

1. Logania falcata Gand., Bull. Soc. Bot. France 70: 921 (1924).

Lectotype (here chosen): 'Buffalo Mts, Victoria', Carl Walter s.n. ex herb Gandoger, Oct 1902 (LY - three specimens on the right); isolectotype: NSW363313. Note: a photograph of the lectotype is available at PERTH1598929. 


\section{Typification}

The type material of L. falcata, as held at LY, consists of four flowering branchlets. The specimen on the left has small strongly recurved to revolute leaves, whereas the other three specimens have longer leaves which are also strongly recurved to revolute, but more falcate than the specimen on the left. Conn (1995a) reduced Logania falcata to the general synonymy of L. albiflora s. lat. specifying that this taxon was in part a synonym of the 'Logania floribunda' variant and in part a synonym of the 'Logania falcata' variant. Conn (loc. cit.) did not lectotypify L. falcata but he did cite the type material under the 'Logania falcata' variant. Although the description of L. falcata, as provided in the protologue (Gandoger 1923), is very brief and slightly ambiguous, the reference to the spreading, elongated and flexuose branches ('Rami patuli elongate flexuosi') (ibid., p. 921) and falcate leaves ('folia ... falcata') more closely describes the three specimens on the right than it does the specimen on the left. Therefore, these three specimens are here selected as the lectotype of $L$. falcata. Since these three collections are referable to the 'Logania floribunda' variant (sensu Conn 1995a, pp. 594 \& 595), Logania falcata is confirmed as a synonym of L. albiflora s. lat., as concluded by Conn.

\section{Logania granitica A.J.Whalen \& B.J.Conn, sp. nov.}

L. albiflorae affinis, a qua foliis sessilibus angustis, inflorescentiis paucifloris (floribus ad 9) differt.

Logania sp. aff. albiflora sensu B.J.Conn, Austral. Syst. Bot. 8: 597-599, fig. 1a (1995a) pro parte (see Notes below).

Logania falcata sensu B.J.Conn, Austral. Syst. Bot. 8: 594 \& 595 (1995a), non Gandoger (1923) (excluding lectotype; see Notes below).

Holotype: Victoria: East Gippsland: summit of Mount Tingaringi [Tingaringy], on border of Victoria and New South Wales, c. $25 \mathrm{~km}$ W of Delegate, A.E. Orchard 2402, 30 Oct 1969 (MEL606972); isotypes: AD, BRI284792, NSW243557.

Illustration: Figure 1a (Conn 1995a).

\section{Description}

Spreading dioecious shrub to $1.5 \mathrm{~m}$ high; branches quadrangular, usually with two pairs of ridges laterally (forming 'angles'), midrib of lamina often extending down internode as a prominent ridge, minutely and densely hairy between the lateral ridges; hairs subpatent, c. $0.1 \mathrm{~mm}$ long. Leaves sessile; petiole not differentiated; stipules up to 1 $\mathrm{mm}$ long, soon reduced to a scarious scar; lamina subcoriaceous, linear, 7-30 $\mathrm{mm}$ long, 1-2.5 mm wide, juvenile leaves or leaves of young plants up to $6 \mathrm{~mm}$ wide [length to width ratio (5-)7-12]; base slightly narrowed, decurrent; margin entire, strongly recurved, such that lower surface hidden; lower surface densely, minutely papillose (margin and midrib glabrous, lacking papillae); upper surface glabrous. Inflorescence axillary, metabotryoidal or botryoidal (variously reduced), usually 3-9-flowered ( $₫),(1-) 3$-flowered ( $q$ ); flowers unisexual, not known if aromatic, with hypopodium ( $\mathrm{a}_{2}$ and $\mathrm{a}_{3}$ axes $) 0.3-0.7 \mathrm{~mm}$ long; anthopodium to $0.1 \mathrm{~mm}$ long; prophylls $0.5-0.8 \mathrm{~mm}$ long, with margin \pm papillate to fimbriate; apex obtuse. Corolla white or cream-coloured, c. $2 \mathrm{~mm}$ long (for both $\delta$ and o ); c. $2 / 3$ connate; tube glabrous, sometimes internally with a thickened rim at mouth, c. $1 \mathrm{~mm}$ long; lobes with outer surface glabrous, inner surface minutely papillose (papillae 
$<0.03 \mathrm{~mm}$ long). Stamens inserted c. $1 / 2$ way up corolla tube; filaments $0.2-0.3 \mathrm{~mm}$ long, glabrous; anthers c. $0.3 \mathrm{~mm}$ long. Pistil $0.5-0.7 \mathrm{~mm}$ long ( $ठ$ ), $0.7-1 \mathrm{~mm}$ long ( $q$ ); ovary and style glabrous; stigma clavate $(\widehat{\sigma})$, ovoid-capitate, \pm bilobed ( $q$ ). Capsule slightly flattened, \pm ellipsoid to \pm cylindrical, 3-5.5 $\mathrm{mm}$ long, 2-2.5 $\mathrm{mm}$ diameter, with style and stigma persisting for some time; seeds few per locule, fawn-coloured, slightly flattenedobloid, 1.8-2.2 mm long, c. $1 \mathrm{~mm}$ wide, minutely papillose.

Flowering: September to November. Fruiting: November to January.

Selected specimens (18 examined): New South Wales: Southern Tablelands: Namadgi National Park: 3 km NW of Booroomba Rocks, Telford 10130, 11 Dec 1985 (CBG8505037, MEL, NSW295665); Booroomba Rocks, Gilmour 5774, 1 May 1986 (CBG8605131, NSW 295668); Below bluff $500 \mathrm{~m}$ SW of Booroomba Rocks lookout, Whalen 619, 23 Nov 2000 (CANB621707, NSW); c. 12 km E of Corin Dam, Adams 3907, 13 Nov 1982 (CANB376724); 1 km S of Tooma Dam wall, Duncan s.n., 8 Nov 1996 (NSW427446, MO, CANB516531); Kosciuszko National Park, W of Tooma Reservoir, Gold s.n., 6 Dec 1994 (NSW414065). Victoria: East Gippsland: Mount Tingaringy summit, Walsh 294, 15 Sep 1979 (MEL595496). Snowfields: Mt Buffalo National Park, Beauglehole 92177, 17 Nov 1987 (MEL1594785). Mt Buffalo, Eagle Point area, Willis s.n., 20 Feb 1963 (MEL2084404); The Watchtower (Neilson Crag), 7.7 km NE from Mt Arbuckle, Walsh 1760, 17 Oct 1987 (MEL1556355, NSW 244441, CBG 8905447).

Distribution: this species extends from Booroomba Rocks (A.C.T. - here included in the Southern Tablelands of N.S.W.) south through Kosciuszko National Park in New South Wales, to Mt Buffalo and Mt Tingaringy in Victoria. Although Logania granitica is distributed over a large area, it is only found on occasional sub-alpine mountain tops within this range. (Fig. 1).

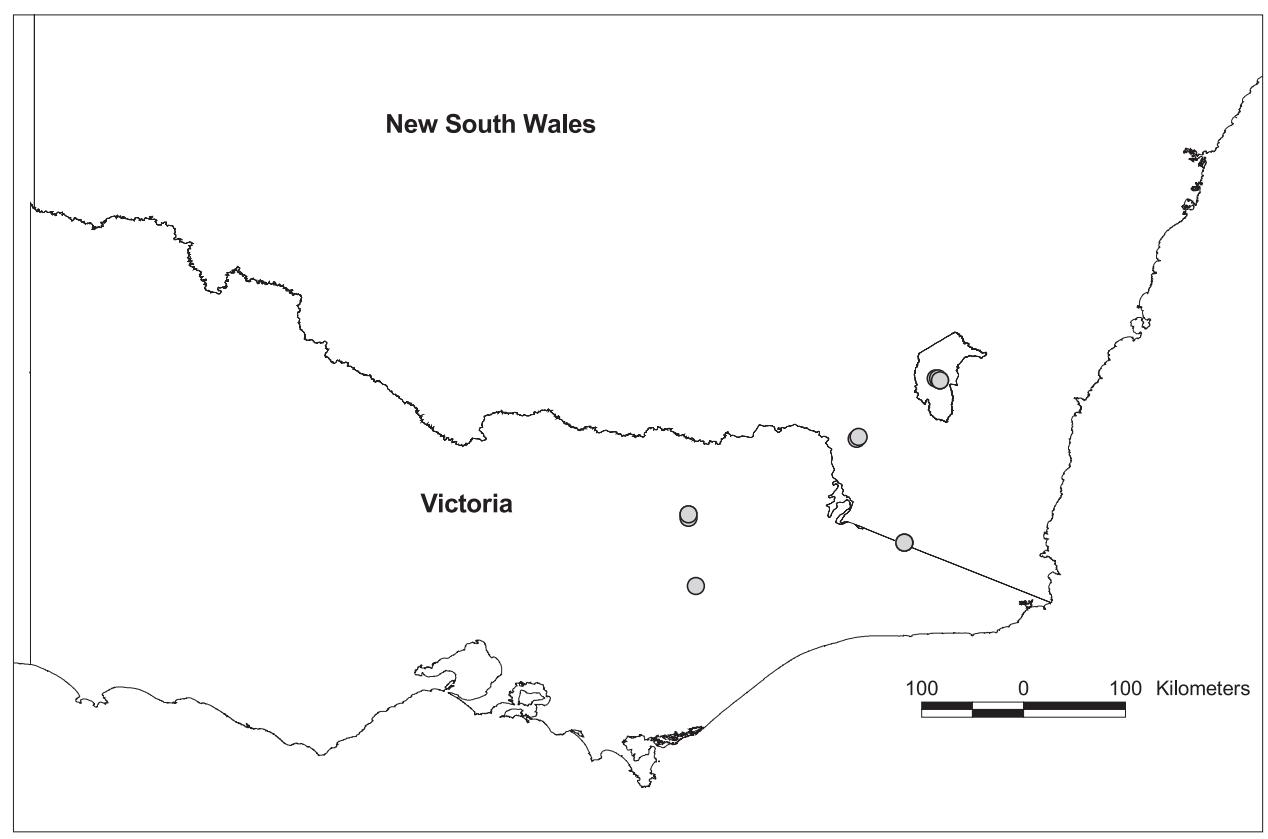

Fig. 1. Distribution map of Logania granitica in southern New South Wales and eastern Victoria. 
Habitat: grows in heathland communities, in Kunzea ericoides-K. muelleri dominated shrublands or in subalpine eucalypt woodlands (dominated by Eucalytus pauciflora, E. stellulata or E. niphophila). It grows on rocky slopes or exposed hilltops in skeletal soils derived from a granitic substrate. This species occurs at high elevations (1200-1450 m).

Etymology: the specific epithet (namely 'granitica') refers to the habitat of large granite boulders amongst which this species dwells.

Notes: although the circumscription of Logania granitica is based on Conn (1995a, pp. 597-599, fig 1a), it has a narrower circumscription than that applied to L. sp. aff. albiflora sensu B.J.Conn (Conn 1995a). The latter taxon is largely included within L. granitica. However, one collection from 'Mongarlowe River' (Cambage s.n. Nov. 1908), identified by Conn (1995a) as Logania sp. aff. albiflora, is here considered to be part of a separate undescribed taxon (Whalen \& Conn in prep.).

The affinities of Logania granitica are not known; however, it is here assumed to be most closely related to L. albiflora s. str.

With the lectotypification of L. falcata (refer above), the remaining specimen of this collection by C. Walter s.n. (LY) belongs to L. granitica. It is presumed that this specimen was gathered from the summit area of Mount Buffalo, whereas the other three specimens were from the slopes leading to the summit.

Conservation status: despite the limited number of known populations and the disjunction between each of these populations, this species is not considered to be at risk. It is thought that most populations are afforded adequate protection because they grow in rugged inaccessible sites within National Park reserves.

Logania granitica is a pioneer species, preferring open sites and responding vigorously to disturbance. In particular, seedlings of this species were found in abundance in the Namadgi National Park after the devastating 2003 bushfires.

\section{Acknowledgments}

We wish to thank Brendan Lepschi, Karina Richards, Marion Garratt, Dave Mallison and Julie Matarzyck (all CANB) for their companionship and assistance with fieldwork. We gratefully acknowledge the Directors and staff of the following herbaria who promptly made available their herbarium collections and/or facilities: BRI, CANB, HO, LY, MEL, NSW, PERTH. The ex situ collections were successfully cultivated at the Australian National Botanic Gardens, Canberra. We thank the staff of these gardens for their expert horticultural assistance. 


\section{References}

Conn BJ (1992) Logania. Pp. 477-479 in Harden GJ (ed.) Flora of New South Wales, vol. 3. (New South Wales University Press: Kensington)

Conn BJ (1993) Natural regions and vegetation of Victoria. Pp. 79-158 in Foreman DB \& Walsh NG (eds) Flora of Victoria, vol. 1. (Inkata Press: Melbourne)

Conn BJ (1995a) Taxonomic revision of Logania Section Logania (Loganiaceae). Australian Systematic Botany 8: 585-665.

Conn BJ (1995b) Description of inflorescence axes in the genus Logania R.Br. (Loganiaceae). Kew Bulletin 50: 777-783.

Gandoger M (1923) Logania falcata and Logania orthophylla. Bulletin de la Société Botanique de France 70: 921.

Harden, GJ (1990) Botanical divisions and subdivisions of New South Wales, pp. viii-ix. Flora of New South Wales, vol. 1 (New South Wales University Press: Kensington)

Manuscript received 04 August 2006, accepted 17 January 2007 